\title{
Nontimber forest product industry in Canada: Scope and research needs
}

\author{
by Luc C. Duchesne ${ }^{1}$, John C. Zasada ${ }^{2}$ and Iain Davidson-Hunt ${ }^{3}$
}

With a current yearly output of \$241 million per year nontimber forest products (NTFP) contribute significantly to the welfare of rural and First Nations communities in Canada. Maple sap products, wild mushrooms and wild fruits are the most important NTFP for consumption both in Canada and abroad. However, because of increased access to international markets by entrepreneurs along with a growing international demand for NTFP it may be possible to double or triple Canada's harvest of NTFP. Further development of this industry should be associated with adequate training of harvesters in terms of NTFP biology in order to maximize profits while achieving biological sustainability. As well, research should emphasize the domestication of specific NTFP to meet growing demand, increase revenues and promote biodiversity conservation.

Key words: forest economics, biodiversity, forest biology, nontimber forest products.

Les produits forestiers non ligneux représentent annuellement des retombées de 241 millions de dollars et contribuent de façon significative au mieux-être des communautés rurales et autochtones du Canada. Les produits de la sève d'érable, les champignons et les fruits sauvages constituent les plus importants de ces produits qui sont consommés autant au Canada qu'à l'étranger. Toutefois, suite à une accessibilité accrue des marchés internationaux par les entrepreneurs en plus d'une demande internationale en croissance pour ces produits, il serait possible de doubler ou de tripler la récolte de produits forestiers non ligneux au Canada. Le développement accentué de cette industrie devrait être associé à une formation adéquate des préposés à la récolte en matière de biologie des produits non ligneux de façon à maximiser les profits tout en atteignant une durabilité biologique. De plus, la recherche devrait porter sur la domestication de certains produits forestiers non ligneux afin de répondre à la demande croissante, accroître les revenus et promouvoir la conservation de la biodiversité.

Mots-clés: économie forestière, biodiversité, biologie forestière, produits forestiers non ligneux

\section{Introduction}

Mankind, including Canadians, has relied on nontimber forest products (NTFP) for food, medicine, clothing and shelter for thousands of years. However, recent international and national successes in the NTFP industry have attracted the attention of politicians, entrepreneurs, economic development agencies and First Nations communities as a means to improve quality of life and reduce poverty in rural Canada (De Geus 1995, Davidson-Hunt 1998, Brubaker 1999, Higgins 1999, Mohammed 1999). Indeed, $80 \%$ percent of the population of the developing world use NTFP for health and nutrition. Several million households worldwide depend heavily on these products for subsistence consumption as well as income (Food and Agriculture Organization 2000). Presently, at least 150 NTFP are significant in terms of international trade, including honey, gum arabic, rattan and bamboo shoots, cork, forest nuts and mushrooms, essential oils, and plant or animal parts for pharmaceutical products. NTFP also provide raw materials for large-scale industrial processing, including for internationally traded commodities such as foods and beverages, confectionery, flavourings, perfumes, medicines, paints or polishes (Food and Agriculture Organization 2000).

In North America, NTFP encompass a wide variety of products derived from forests, including conifer boughs, wild rice, wild blueberries, maple sap products, wild mushrooms and wild medicinal herbs. In British Columbia, 200 types of NTFP

${ }^{1}$ Canadian Forest Service, 1219 Queen St. E., Sault Ste. Marie, ON P6A 5M7. E-mail: luduches@nrcan.gc.ca. Corresponding author.

${ }^{2}$ U.S.D.A. Forest Service, North Central Research Station, Grand Rapids, MN USA 55744.

${ }^{3}$ Taiga Institute for Land and Culture, Kenora, ON P9N $1 E 9$.

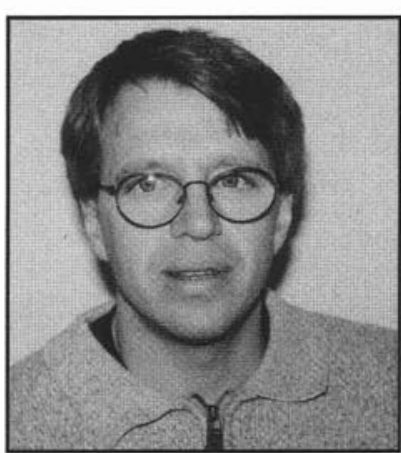

Luc Duchesne

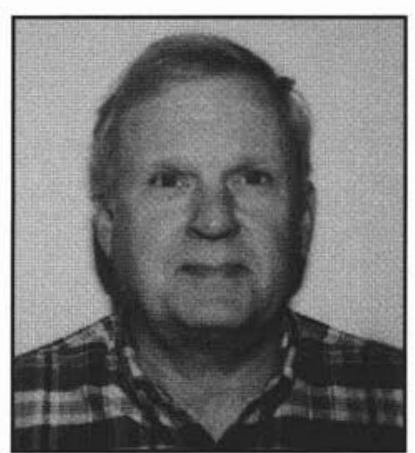

John Zasada are recognized, whereas in Ontario 50 types are commercially used (Mohammed 1999), although we surmise that there may be as many as 500 NTFP in Canada. In the Michigan's Upper Peninsula, Emery (1998) documented the harvest of various plant parts from more than 132 tree, shrub and herb species by residents for commercial sale and personal use.

For the purpose of this paper we define NTFP as nontimber products growing in forests and derived from plants or animals in their natural environment (Ciesla 1998). However, we are excluding animal products from this discussion because of wildlife regulations that control and/or prohibit the sale of such products in many Canadian provinces. Applied broadly, our definition also includes logging residues such as branches, stumps, or rotten logs that have been culled during timber harvesting operations. As well, we are omitting products such as American ginseng and Christmas trees that have been domesticated for cultivation in agricultural settings. 
Although many NTFP can be harvested successfully for profit in the short term, the long term sustainability of the NTFP industry depends on a thorough understanding of the biological and ecological factors controlling their abundance and distribution. This need is threefold. First, it is essential to understand how NTFP grow in order to promote their conservation through sustainable harvesting and cultural techniques. Second, gatherers and entrepreneurs need to understand the biology of NTFP in order to optimize harvesting operations. And third, some NTFP will eventually require domestication to meet demands and avoid depleting the sustainability of the natural harvest. To achieve this, a sound understanding of NTFP genetics, biology, and ecology will be needed. In this paper we present an overview of the current NTFP industry in Canada and we discuss the research needs dealing with the biology and ecology of NTFP to further expand this industry.

\section{Canada's current NTFP harvest}

We have surveyed the value of NTFP shipments by contacting entrepreneurs, local and regional economic development agencies, academics, consultants in the fields of NTFP and government agencies. We report our findings for 1997 in Table 1, illustrating a total yearly value of approximately \$241 million in NTFP harvests. At present, maple sap products and wild mushrooms make up the bulk of Canada's NTFP output for national consumption and international export (Table 1), whereas wild berries, medicinal plants and other NTFP play a less important economic role. Interestingly, wild mushrooms are mostly harvested for international markets. For example, the value of pine mushrooms exported from British Columbia to Japan exceeds $\$ 40$ million per year. One limitation of our study is that we were unable to assess the commercial value of NTFP harvested for personal use as well as NTFP that are traded through the underground economy.

The contribution of NTFP to Canada's forest sector is small as it is only $0.4 \%$ of the yearly $\$ 58.7$ billion output in forest products. However, NTFP play a critical socioeconomic role at the regional level as they contribute greatly to rural economies through seasonal employment and often allow families to increase their annual disposable income by $\$ 5000-\$ 10000$. For example, the harvest of wild blueberries in the Lac-St-Jean area of Quebec provides harvesters with up to $\$ 5000$ per year in spending money. In view of the fact that unemployment is high in Lac-St-Jean, blueberry harvesting helps reduce poverty and improve quality of life, particularly for First Nations communities with unemployment as high as $80 \%$.

Currently, the two greatest impediments to the expansion of the NTFP industry in Canada is the lack of inventory data on the abundance of NTFP and the limited knowledge of entrepreneurs about international markets. Hence it is difficult to determine the actual potential of NTFP outputs in Canada. However, for the purpose of this discussion we estimate the potential of the NTFP harvest at $\$ 1$ billion per year based on two approaches: 1) the current yield of NTFP is limited to less than $\$ 1.00$ per ha of productive forest land ( 233 million ha, National Forestry Database: http://nfdp.ccfm.org/frames2_e.htm) and so, we hope that this figure can be increased four- to five-fold through exploiting new markets and products; and, 2) there is a high demand for various types of NTFP by international markets while local pilot studies suggest that NTFP harvesting may meet those
Table 1. Estimated Nontimber Forest Products in Canada - value of annual shipments for 1997.

\begin{tabular}{ll}
\hline Maple syrup & $\$ 120000000$ \\
Mushrooms & $\$ 100000000$ \\
Berries (Vaccinium spp., Amelanchier spp.) & $\$ 20000000$ \\
Medicinal plants & $\$ 1000000$ \\
Ornamentals & $\$ 500000$ \\
Essential oils & $\$ 50000$ \\
\hline Total value of shipments & $\$ 241000000$
\end{tabular}

Table 2. Value of shipments from Canada's timber industry for 1997.

\begin{tabular}{ll}
\hline Newfoundland & $\$ 603000000$ \\
Nova Scotia & $\$ 1009000000$ \\
New Brunswick & $\$ 2960000000$ \\
Quebec & $\$ 15102000000$ \\
Ontario & $\$ 12059000000$ \\
Manitoba & $\$ 702000000$ \\
Saskatchewan & $\$ 714000000$ \\
Alberta & $\$ 3482000000$ \\
British Columbia & $\$ 22039000000$ \\
\hline Total Canada & $\$ 58700000000$
\end{tabular}

Source: Statistics Canada

demands (Miron 1994, Duchesne 1995). At \$1 billion per year, our predicted NTFP potential is comparable to the total value of timber product shipments from Manitoba, Newfoundland and Saskatchewan for 1997 (Table 2).

There are two models for gathering and marketing NTFP: 1) intensive harvesting and marketing of single products; and, 2) intensive harvesting of multiple products. On the one hand, NTFP that are in high demand and fetch high values to harvesters can help create single-product industries such as the pine mushroom, morel and blueberry operations. Typically, employment in this type of industry is seasonal and is heavily influenced by factors controlling the abundance and market value of their target product. On other hand, multiple-product harvesting operations are less sensitive to the commodity-type fluctuations in the values of NTFP as a large number of products are harvested by harvesters. Emery (1998), for example, has developed an annual calendar showing the "normal" times of collection/harvest of many products in the forests of northern Michigan. Her analysis suggests that gatherers who collect multiple species can time their activities for the generation of revenues for all months of the year. As well, because several NTFP are harvested, the risks associated with poor harvest or low market values are reduced as compared to single-product harvesting operations.

\section{Ecological knowledge and NTFP profitability}

The future of the NTFP industry depends largely on entrepreneurs gaining the necessary knowledge to locate, harvest, handle and transport NTFP as efficiently as possible. In turn, it is critical for forest biologists to assist NTFP harvesters with knowledge that helps them in selecting the more profitable sites, harvesting in an efficient and ecologically sound way, and handling their products for maximum economic returns. Although a vast body of scientific literature and practical experience teaches forest users that plants are not found uniformly throughout the forests, there is very little knowledge relating to the spe- 
cific needs of the NTFP industry. Particularly, we have a poor understanding of the specific biology of many NTFP, and so it is difficult to pinpoint their location and abundance in natural ecosystems. In practice, NTFP distribution varies with a wide range of environmental and internal plant factors, such as soil conditions, climate, time of the growing season, history of disturbance, vegetation type, and plant age and condition. As well, it is important to recognize that within forest ecosystems not all NTFP sources are equally desirable. For example, the quality of birch bark varies among trees in a stand and between birch stands, as does the pattern of annual ring width of black ash trees, an important factor in selection of trees for basketry (McPhee 1989, Collins 2000). As well, in western Canada, morel harvesters visit recent wildfire sites in search of black morels. Because black morel fruiting takes place early in the growing season (Duchesne and Weber 1983), harvesters start their harvesting operations in the south of the boreal forest and progressively migrate north as the morel season is initiated.

There are several considerations that should be kept in mind regarding the effect of disturbance on NTFP. First, where it is possible, gatherers of NTFP should be directed to areas where forestry operations will impact NTFP species that are associated with mature forests. For example, in areas where there is a balsam bough market, and a timber sale will severely damage a balsam fir understory, bough pickers should be allowed to harvest this material before it is destroyed. Second, there are many disturbances - forest harvesting is a primary example - that result in an increase in NTFP production such as fruits and berries. Where it is possible, these areas should be identified and gathering for personal and commercial use encouraged. Similarly, fire-disturbed forests should be envisioned by forestry agencies as sources of fire-dependent mushrooms.

\section{Ecological knowledge and the domestication of NTFP}

The ecological sustainability of the NTFP harvest is critical for this industry. Undoubtedly, the impact of the evolution of harvesting operations from subsistence level to intensive commercial exploitation will create new pressures on individual species and ecosystems as well as conflicts with other forest users. Indeed, whereas traditional use of NTFP by First Nations People was limited by technology, the large-scale use of NTFP utilizing modern means of extraction and transportation can have a great impact on individual species and ecosystem productivity. A good example is the fact that American ginseng is now endangered in Canada from 50 years of excessive harvest.

Substantial revenues are currently derived from the domesticated production of NTFP and there are many advantages to the domestication of more NTFP for both economic and ecological reasons. Domestication can take different forms, depending on product, sites, and economic considerations. For example, blueberry producers in eastern Canada manage natural populations of plants (Smith and Hilton 1971) while in Minnesota and elsewhere domestication of blueberries takes the form of planting and cultivating desired varieties. In Canada, the Christmas tree industry alone yielded \$60 million in 1998 (Natural Resources Canada 1998) whereas the American ginseng harvest from agricultural lands in Ontario yields revenues of more than \$40 per year (Mohammed 1999). Reasons for domesticating these NTFP included maximizing harvest, avoiding further depletion of natural stocks, stabilizing supplies and increas- ing economic return. The intensive culture of American ginseng in former tobacco fields of southern Ontario had the double advantage of providing tobacco farmers with an alternative crop when the tobacco demand fell and helped preserve natural stocks. However, the success of ginseng domestication is largely due to our understanding of its ecological requirements for seed stratification, nutrient needs and shading, although field-grown ginseng is inferior in quality as compared to wild ginseng, owing to the lower content of active ingredients in the former (Ma et al. 1995). Further research showed that ginseng grown under the canopy of a forest stand is of better quality (Beyfuss 1999). Other NTFP, particularly wild mushrooms, could become domesticated if we understood their ecological requirements.

Understanding the biology of mushrooms, Canada's second most important group of NTFP, is a good example of the complexity of the research needs for domestication. From an NTFP perspective, there are two types of fungi: those that feed on dead material - also known as saprophytic fungi, and fungi that form symbiotic associations with plants - generally called mycorrhizal fungi. In general, saprophytic fungi are easier to cultivate than the symbiotic fungi. For example, the massproduced agaric, shiitake and oyster mushrooms are saprophytic species that have been domesticated. In contrast, symbiotic fungi are difficult to cultivate because of they need the presence of a symbiotic tree in order to fruit. Unfortunately, the most valuable wild mushroom species, such as the chanterelles, the boletes and the pine mushroom are symbiotic species and their domestication has not been achieved. However, cultivation of Laccaria species has recently been reported through the co-incubation of both fungi and a host plant under controlled conditions (Godbout and Fortin 1990).

\section{Conclusions}

Because of increases in the global demand in NTFP and the globalization of commerce the harvest of NTFP is becoming more attractive in the economic development of rural and First Nations communities. As Canadians become more aware of the economic potential of the NTFP industry there is a need to further augment our knowledge base in order to create a sustainable industry. Two general types of knowledge are available regarding NTFP. First, historic or traditional knowledge has been gleaned and "field tested" by countless generations of First Nations people, Canadians of various ethnic origins, and consumers of NTFP. Often, this information far exceeds the scientific knowledge available for a particular product (Richards 1997). First Nations people have a great deal of experience in the management of berries, roots, and other materials essential to their lives. These include the use of fire, harvesting techniques, planting, and various levels of cultivation. Even today, modern technology takes advantage of approaches borrowed from the First Nations people to reduce annual periodicity, increase production, and reduce natural variation in the occurrence of some NTFP. The second type of knowledge necessary to the NTFP industry, scientific knowledge, is gained through the study of the natural history of plants and hypothesis testing using experimental techniques. In our experience both traditional knowledge and scientific knowledge have important roles to play in the sustainable production of NTFP. When traditional knowledge is not available, basic principles of plant reproduction and growth should provide a guide 
for developing practices for sustainable use of the NTFP resource. Scientific knowledge can also be used to explain the biological basis for the success of well-tested traditional methods of NTFP harvest and utilization. Understandably, the bulk of our knowledge dealing with Canada's forests deals with species that are affected and/or needed by timber harvesting operations. However, the development of the NTFP industry will lead to NTFP-specific new knowledge that will contribute to our increasing NTFP culture and should promote the conservation of Canada's forest biodiversity.

Fueled by increased knowledge of the economic potential of NTFP, the near future should yield exciting new developments in this field. In turn, an expanding new NTFP industry will require the forestry profession to adapt to novel uses of the forest resources. Whereas NTFP operations have been overlooked by mainstream forest agencies, there is a growing need for governments to take an active role to facilitate the development of the NTFP industry through research and technology. Ultimately, the NTFP industry should become a strong contributor to the Canadian forest sector and the Canadian economy.

\section{References}

Beyfuss, R.L. 1999. American ginseng production in woodlots. Agroforestry notes. USDA, National Agroforestry Center, Lincoln, Nebraska. AF note 14 Forest farming. 34 p.

Brubaker, D. 1999. Non timber forest products: exploring opportunities for Aboriginal communities. National Aboriginal Forestry Association, Ottawa, Ont. 135 p.

Ciesla, W.M. 1998. Non timber forest products from conifers. Food and Agriculture Organization of the United Nations, Rome, Italy. Non wood forest product $12.124 \mathrm{p}$.

Collins, M. 2000. Age structure, growth, and regeneration of Fraxinus nigra populations in the upper Great Lakes states. Masters thesis. Michigan Technological University. 36 p.

Davidson-Hunt, I. 1998. Non timber forest products-definitions and meanings. Taiga Institute, Kenora, ON. Boreal Culturescapes Newsletter 1:2-3.

De Geus, P.M.J. 1995. Botanical forest products in British Columbia: an overview. Integrated Resources Policy Branch, British Columbia Ministry of Forests, Victoria, BC. 51 p.

Duchesne, L.C. 1995. Commercial potential of wild mushroom harvest in Renfrew County. Unpublished report. 10 p.

Duchesne, L.C. and M.G. Weber. 1993. High incidence of the edible morel Morchella conica in a Pinus banksiana forest following prescribed burning. Canadian Field Naturalist 107: 114-116.

Emery, M. R. 1998. Invisible livelihoods: non-timber forest products in Michigan's upper peninsula. Ph. D. thesis, Rutgers Univ., New Brunswick, NJ.

Food and Agriculture Organization. 2000. Non-wood forest products. Forestry Information Note http://www.fao.org/WAICENT/ FAOINFO/FORESTRY/NWFP/NONWOOD.HTM.

Godbout, C. and J. A. Fortin. 1990. Cultural control of basidiome formation in Laccaria bicolor with container-grown white pine seedlings Mycological Research 1990: 1051-1058.

Higgins, C. 1999. Innovative forestry practice agreements - What could be done that would be innovative. For. Chron. 75: 939-942.

Ma, Y.C., J. Zhu, L. Benkrima, M. Luo, L.H. Sun, S. Sain, K. Kont and Y.Y.Y Plaut-Carcasson, YY. 1995. A comparative evaluation of ginsenosides in commercial ginseng products and tissue culture samples using HPLC. Journal of herbs, spices \& medicinal plants. 1995(3): 41-50.

McPhee, J. 1989. The survival of the bark canoe. Noonday Press. Miron, F. 1994. Woodland mushrooms: harvesting and marketing. Champignons Laurentiens Inc. Berry, Que. 56 p.

Mohammed, G.H. 1999. Non timber forest products in Ontario. Ontario Forest Research Institute, Sault Ste Marie, Ont. Forest Research Information Paper No 145.64 p.

Natural Resources Canada. 1999. The State of Canada's Forests. Natural Resources Canada, Ottawa, Ont.

Richards, R.T. 1997. What the Natives Know. Wild mushrooms and forest health. J. For. 95: 5-10.

Smith, D.W. and R.J. Hilton. 1971. The comparative effects of pruning by burning or clipping lowbush blueberries in northeastern Ontario. J. Appl. Ecol. 8(3): 781-789. 